\title{
Morphological Development of Eggs, Larvae and Juveniles of the Far Eastern Catfish, Silurus asotus in Korea (Pisces: Siluridae)
}

\author{
Seong Jun Mun ${ }^{1}$, Hu Sun Yim ${ }^{1}$, Kyeong Ho Han² and ${ }^{\dagger}$ Jae Min Park $^{1}$ \\ ${ }^{1}$ Gyeongsangbuk-Do Native Fish Business Center, Uiseong 37366, Korea \\ ${ }^{2}$ Dept. of Aqualife Science, Chonnam National University, Yeosu 59626, Korea
}

\begin{abstract}
This study was conducted to investigate egg development and larvae morphological development of catfish and to provide basic data to clarify the genetic relationship with Siluriformes fish. The mother fish that was used in this study was caught in the stream of Nakdong River in Uiseong-gun, Gyeongbuk. The temperature range of the breeding was 23.0$25.0^{\circ} \mathrm{C}$ (mean $24.0 \pm 1.0^{\circ} \mathrm{C}$ ) and egg size was 1.62-1.70 mm (mean 1.66 $\pm 0.05, \mathrm{n}=30$ ). Eggs of catfish began hatching at 54 hours and 40 minutes after fertilization. Immediately after hatching, the total length of larvae was 3.60-3.65 mm (mean $3.62 \pm 0.03, \mathrm{n}=5$ ) and had an egg yolk without swimming ability. On the third day after hatching, the larvae at the medium stage was 8.00-8.65 mm (mean 8.32 \pm 0.45 ) in total length, and two pairs of whiskers formed around the mouth were elongated. On the 12th day after hatching, the larvae at the juvenile stage was 16.5-17.0 mm (mean 16.7 \pm 0.35 ) in total length, and the stem of each fin was in the range, and the juvenile at this period was morphologically similar to the mother fish.
\end{abstract}

Key words : Egg development, Far eastern catfish, Juvenile, Larva, Silurus asotus

\section{INTRODUCTION}

Catfish (Silurus asotus) belongs to Siluriformes, family of Siluridae, and Genus Silurus, and there are one genus and two species such as catfish and Silurus microdorsalis, etc. inhabiting in Korea. It is known that there are about 12 genera and 100 species of catfish inhabiting around the world. It is distributed mainly in rivers and lakes such as Japan, Taiwan and China including Korea (Kim \& Lee, 1993; Kim et al., 2005).

Catfish is one of the most representative varieties of domestic catfish, along with channel catfish Ictalurus punctatus, and it has a taste better than channel catfish, attracting consumers' attention with Maeuntang-stew and steamed catfish dishes. Especially, it is possible to breed high density, and to induce rapid growth by feeding compound feed, and many forms of farming are being made in Korea (Yu et al., 2009).

A number of studies over catfish were conducted in terms of sperm microstructure (Kwon et al., 1998), gynogenesis diploid induction ( $\mathrm{Im}$ et al., 2000), domestic catfish epithelium (Yu et al., 2009), and Pathological changes (Kim et al., 2013), etc. However, there is a lack of data on egg development and larvae morphological development in catfish inhabiting in Korea.

The data for the early development of catfish are briefly described in aquaculture publications published by national and provincial research institutes, but it is true that

\footnotetext{
Manuscript received October 17, 2017, Received in revised form November 11, 2017, Accepted November 21, 2017

${ }^{\dagger}$ Corresponding Author : Jae Min Park, Gyeongsangbuk-Do Native Fish Business Center, Uiseong 37366, Korea. Tel: +82-54-830-8800, Fax: +82-54830-8809, E-mail: gost016803@naver.com

This is an Open Access article distributed under the terms of the Creative Commons Attribution Non-Commercial License (http:// creativecommons.org/licenses/by-nc/3.0) which permits unrestricted non-commercial use, distribution, and reproduction in any medium, provided the original work is properly cited.
} 
no specific research data have been established.

Therefore, in this study, we attempted to observe the egg development and larvae morphological development of Korean catfish and find a genetic relationship with the same Siluriformes fish in Korea, to preparetaxonomic study data and utilize it as a basic data for aquaculture and seed production.

\section{MATERIALS AND METHODS}

\section{Broodstork fish management}

The broodstork fish used in this study was caught in the Wicheon stream located in Bian-myeon, Uiseong-gun, Gyeongbuk Province between May and June 2016, and transported it to the laboratory, where it was hydroponically raised in a $6 \mathrm{~m}$ diameter round water tank of PVC (Polyvinyl chloride). The water temperature ranged from 23.0 to $25.0^{\circ} \mathrm{C}$ (mean $24.0 \pm 1.0^{\circ} \mathrm{C}$ ). The breeding water was recovered more than $50 \%$ once a day, and the dry feed (Dry feed, Jeilfeed Korea) was supplied twice a day.

\section{Egg-stripping}

For egg-stripping, the females selected were 30.5-43.3 (mean 36.9 $\pm 9.05, \mathrm{n}=3$ ) $\mathrm{cm}$ in abdomen smooth and bloated, and the circumference of reproductive tract was red. To induce artificial maturation, 10,000 IU of human chorionic gonadotropin (HCG) was injected into the dorsal muscle area, and then harvested 24 hours later by abdominal compression. The males selected were 29.8-30.3 (mean 30.0 $\pm 0.35, \mathrm{n}=3$ ) $\mathrm{cm}$ in total length and the genitalia were distinct. The testis was extracted through abdominal incision with MS-222 (Tricaine methane sulfonate; Sindel Co., Canada) after anesthesia. The extracted testis was diluted in physiological saline $(\mathrm{NaCl} 0.9 \%)$ and artificially fertilized with the eggs.

\section{Egg development process and larvae morpho-} logical development

30 embryos were selected and placed in a $500 \mathrm{~mL}$ glass beaker. Breeding water temperature was the same as the mother control temperature and the aeration was weakened to supply oxygen. Egg morphology was observed and sketched using a phase contrast microscope (LEICA EZ4 HD, Germany) to observe the egg development process. And the size of the egg was measured to $0.01 \mathrm{~mm}$ using a universal projector (Nikon JP V-12B, Japan).

As for larvae morphology development, five larvae were selected daily from day 0 after hatching until day 12 after hatching to reach a juvenile stage, and were measured up to $0.01 \mathrm{~mm}$ using a universal projector. Then, morphological features were observed using a stereomicroscope and then sketched.

The developmental process of larvae was classified according to Kendall et al. (1984). We did not feed the larvae during the egg yolk absorption period from 0 day after hatching to 3 day after hatching. At the time of egg yolk absorption ending from the 3rd day after hatching to the 12th day after hatching, we supplied Artemia sp. Nauplius to 2-3 individuals per $\mathrm{ml}$. three times per day. The compound feed was fed six times daily from day 12 after hatching. Larvae were screened once a week according to the size to prevent cannibalism during the growth process.

\section{RESULTS}

\section{Size and characteristics of eggs}

The embryos of the catfish were globular sinking cohesive eggs, surrounded by a mucosal mass on the surface, and the size of the eggs ranged from 1.62 to $1.70 \mathrm{~mm}$ (mean 1.66 $\pm 0.05, \mathrm{n}=30$ ).

\section{Egg development process}

Immediately after fertilization, the eggs began to absorb water (Fig. 1A), the blastula was formed $10 \mathrm{~min}$ after fertilization (Fig. 1B), and an hour after fertilization, it reached the two cell stage (Fig. 1C). At 2 hours and 15 
minutes after fertilization, it reached the 4-cell stage (Fig. 1D) and reached the 8-cell stage at 2 hours and 40 minutes after fertilization (Fig. 1E).

At 4 hours and 20 minutes after fertilization, it reached the 16-cell stage (Fig. 1F), and at 5 hours after fertilization reached the 32 cell stage (Fig. 1G). At 4 hours and 50 minutes after fertilization, it reached the 64 cell stage (Fig. 1H). 6 hours and 30 minutes after fertilization, it reached the morula stage (Fig. 1I), and at 7 hours and 50 minutes after fertilization, it reached the blastula stage with covering egg yolk and falling (Fig. 1J). At 11 hours and 50

A

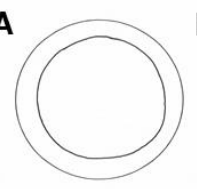

B
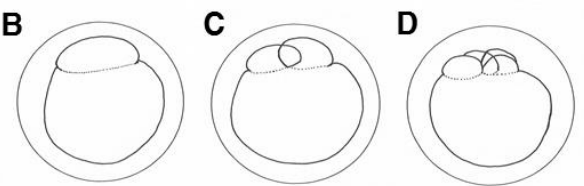

E

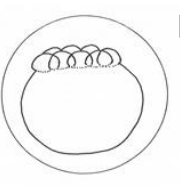

F

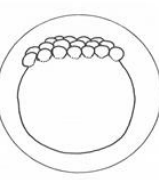

G

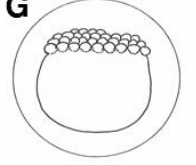

H

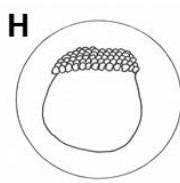

I
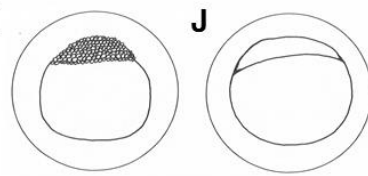

$\mathbf{K}$

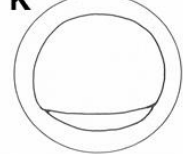

$\mathbf{L}$
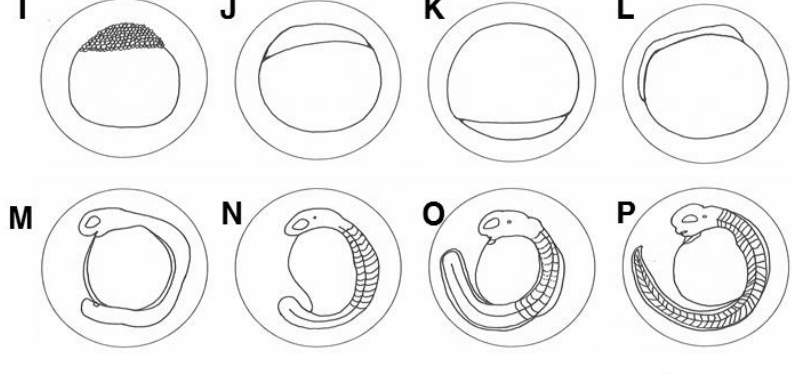

Fig. 1. Egg development of far eastern catfish, Silurus asotus. A: Fertilized egg; B: Blastodisc formed, 10 min post-fertilization (PF); C: 2cells, 1 hour postfertilization (hPF); D: 4cells, $2 \mathrm{hPF} 15 \mathrm{~min}$; E: 8cells, 2 hPF 40 min; F: 16cells, 4 hPF 20 min; G: 32cells, 5 hPF; H: 64cells, 5 hPF 50 min; I: Morula stage, 6 hPF 30 min; J: Blastula stage, 7 hPF 50min; $\mathrm{K}$ : Gastrula stage, $11 \mathrm{hPF} 50 \mathrm{~min}$; L: Formation of embryo, 14 hPF 20 min; M: Disappear of Kuffer's vesicle, $17 \mathrm{hPF} 20 \mathrm{~min}$; N: Number of myotomes 15 17, 22 hPF 20 min; O: Heart beating, 34 hPF 20 min; P: Just before hatching, $54 \mathrm{hPF} 40 \mathrm{~min}$. Scale bar $=1.0 \mathrm{~mm}$. minutes after fertilization, the yolk was completely covered to form an embryo (Fig. 1K), and at 14 hours and 20 minutes after fertilization, an egg was formed in the upper part of the egg yolk (Fig. 1L). At 17 hours and 20 minutes after fertilization, the head was developed in the embryo and Kuffer's vesicle was formed at the tip of the tail (Fig. 1M).

Kuffer's vesicles disappeared at 22 hours and 20 minutes after fertilization, and 15-17 incisions were formed (Fig. $1 \mathrm{~N})$. At 34 hours and 20 minutes after the fertilization, the tail was formed with fins and the length was elongated and separated from the egg yolk. The movement of the embryo began to increase, and the heart was formed in front of the egg yolk (Fig. 1O).

At 54 hours and 40 minutes after fertilization, the embryo began to rotate clockwise, and the number of revolutions per minute was 1 to 2 revolutions per minute. The mouth was formed in the head but not completely opened, and the brain was differentiated, and hatching started from the tail through the egg membrane (Fig. 1P). At the 60th hour after fertilization, more than $50 \%$ of the total fertilization was completed, and the fertilization of all eggs was completed at 63 hours after fertilization.

\section{Larvae morphological development}

\section{1) Larvae at the early stage}

The process of morphological development of catfish larvae is shown in Fig. 2. Immediately after hatching, the larval fish at the early stage had a total length of 3.60-3.65 $\mathrm{mm}$ (mean 3.62 $\pm 0.03, \mathrm{n}=5$ ). It had an egg yolk, and an anal was formed but it was not fully opened. The dorsal fin continued from the back of the head to the tip of the yolk of the lower abdomen. The hatched larval fish did not have swimming ability but the tail part was active and there were no development in the lens or pupil of eyes (Fig. 2A).

The larval fish at the early stage on the first day after hatching was 3.84-3.55 mm (mean 3.69 \pm 0.20 ) in total length. Short protrusions formed around the mouth were elongated 
and developed into two pairs of whiskers, and pigmentation was deposited in the eyes. The mouth began to open gradually, the anus was fully open, and the egg yolk was not fully absorbed. Black vesicles were deposited with small branches of black vesicles in the upper part of the head, upper part of the egg yolk, and back to the tail end. The fins were membranous and divided on the anus (Fig. 2B).

\section{2) Larval fish at the medium stage}

On the third day after hatching, the larval fish at the medium stage was $8.00-8.65 \mathrm{~mm}$ (mean $8.32 \pm 0.45$ ). The

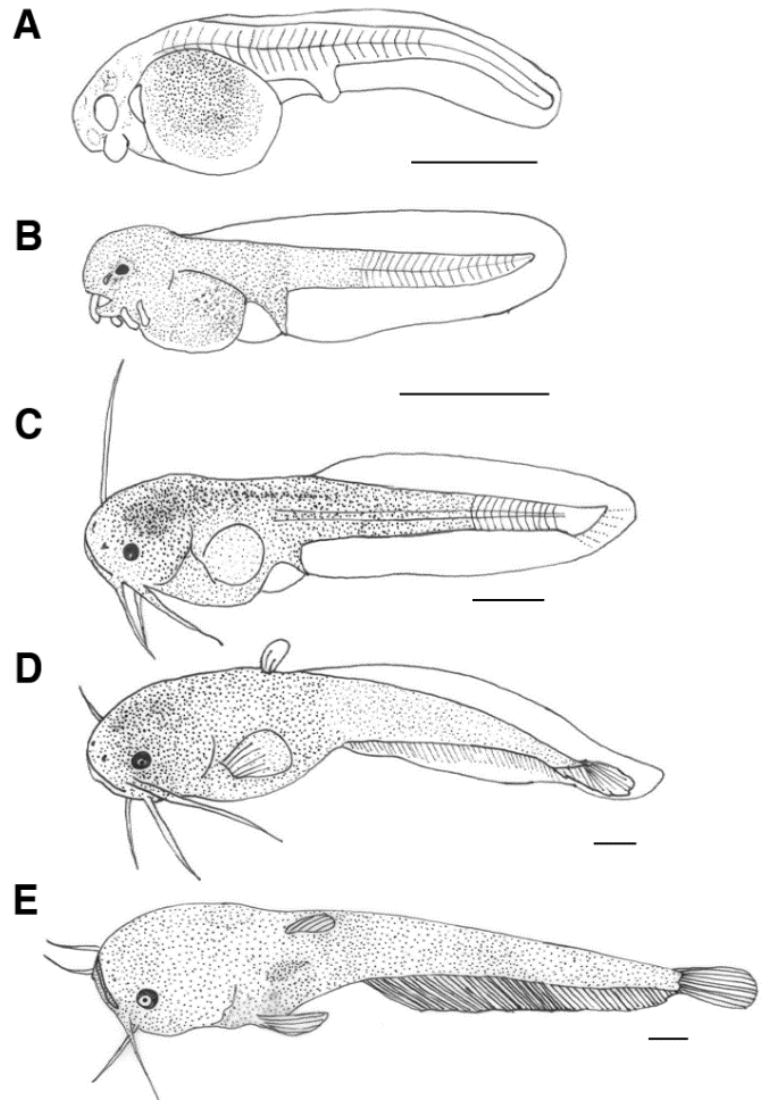

Fig. 2. Morphological development of preflextion and flextion and postflextion and juveniles of far eastern catfish, Silurus asotus. A: Newly hatched larvae, mean $3.62 \mathrm{~mm}$ TL (total length); B: 1 days after hatching $(\mathrm{dAH})$, mean $3.69 \mathrm{~mm} \mathrm{C:} 3 \mathrm{dAH}$, mean $8.32 \mathrm{~mm}$ D: $6 \mathrm{dAH}$, mean $15.0 \mathrm{~mm} \mathrm{E}: 12$ $\mathrm{dAH}$, mean $16.7 \mathrm{~mm}$. Scale bars $=1.0 \mathrm{~mm}$. two pairs of whiskers formed around the mouth were elongated, and the egg yolk was mostly absorbed and they began to eat food. The position of the dorsal fin was the same in the back and lower part, and the pectoral fins were formed in a round shape. The tip of the tail started to bend at $45^{\circ}$ and the stem began to develop in the dorsal fin. The larval fish began to swim up and down the wall of the tank, and the opening and closing mouth movements were observed (Fig. 2C).

\section{3) Larval fish at the later stage}

On the 6th day after hatching, the larval fish at the later

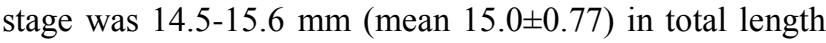
and two stems were formed in dorsal fin. The number of fins formed in each part was 6 pectoral fins, 14 caudal fins, 55-60 anal fins, and the pelvic fins were membrane (Fig. 2D).

\section{4) Larval fish at the juvenile stage}

On the 12th day after hatching, the larval fish at the juvenile stage was 16.5-17.0 mm (mean 16.7 \pm 0.35 ), and the lens was differentiated in the eyes. The number of stems of each part of fins increased to 4-5 dorsal fins and 71-83 anal fins, reaching the integer (fixed number). During this period, small spots of black vesicles were deposited throughout the body, and external morphological features were similar to those of the mother fish. As juvenile diets increased, individual differences in size began to appear, leading to the formation of large populations eating small individuals (Fig. 2E).

\section{DISCUSSION}

The individual development of fish repeatedly indicates the characteristics of the system. Studies on the early life history of fish have included morphological and ecological characteristics of eggs, and the inherent traits and developmental characteristics of the fish species that occur during 
Morphological Development of Eggs, Larvae and Juveniles of the Far Eastern Catfish, Silurus asotus in Korea (Pisces: Siluridae)

embryo genesis and early growth process. In addition, studies on the early life history, such as egg development and larvae development, can be important basic data for studying the genetic relationship between similar species (Song \& Choi, 2000; Choi et al., 2008; Kim et al., 2014).

Catfish spawning season is known to be mainly from late spring to early summer, and the case of being cultured for seed production is mainly harvested between April and May (Kwon et al., 1996). When wild catfish were caught, the maturation period was observed from April to June, and the cultured catfish and egg laying period were found to be similar.

In spawning places, there are relatively slow water flow and sands and gravel on the floor. Males are known to use the tail and trunk to wrap a female whose abdomen is bloated and then to lay eggs and fertilize it at the same time. Whereas the eggs of channel catfish that is the same Siluriformes fish, are collected and hatched artificially when the eggs are scattered in the hiding place after females and males have spawned, the catfish differed from channel catfish in egg-stripping with artificial maturation using hormones for planned seed production and wild eggbased embryos. The egg-stripping method for the Siluriformes fish was shown in Pseudobagrus fulvidraco (Kang \& Lee, 1996), Leiocassis ussuriensis (Park et al., 2015) and L. longirostris (Lim et al., 2012).

The embryos of catfish were spherical sediments and the mean diameter was $1.66 \pm 0.05 \mathrm{~mm}$. In comparison with the same species of Siluriformes, it was smaller than the mean diameter of Liobagrus mediadiposalis (Choi et al., 2008) of $3.27 \mathrm{~mm}, L$. obesus (Seo et al., 2006) of $3.30 \mathrm{~mm}, L$. ussuriensis (Park et al., 2015) of $2.36 \pm 0.11 \mathrm{~mm}$ and $P$. koreanus (Kang, 1998) of $2.59 \pm 0.08 \mathrm{~mm}$, and it was larger than that of P. fulvidraco (Kang \& Lee, 1996) with a mean egg diameter of $1.70 \pm 0.08 \mathrm{~mm}$ and P. brevicorpus (Kang et al., 2007) with a mean egg diameter of $1.99 \mathrm{~mm}$.

In case of the catfish, the time required for hatching was 54 hours and 40 minutes when the average water tempe- rature was $24.0 \pm 1.0^{\circ} \mathrm{C}$. The same Siluriformes fish, $L$. ussuriensis (Park et al., 2015) took 73 hours and 10 minutes when the average water temperature was $25.0 \pm 0.05^{\circ} \mathrm{C} . P$. fulvidraco (Kang \& Lee, 1996) took 53 hours at a water temperature of $25.0^{\circ} \mathrm{C}$, P. koreanus (Kang, 1998) took 72 hours at a water temperature of $21.0-23.0^{\circ} \mathrm{C}$, and P. brevicorpus (Kang et al., 2007) took 50 hours at a water temperature of $24.0^{\circ} \mathrm{C}$. L. mediadiposalis (Choi et al., 2008) took 189 hours and 20 minutes at a temperature of $22.5^{\circ} \mathrm{C}$, and L. obesus (Seo et al., 2006) took 225 hours and 15 minutes at a temperature of $22.8^{\circ} \mathrm{C}$. There was a tendency that the higher the water temperature, the shorter, the time required for hatching of Siluriformes fish. The catfish took longer time for hatching than P. brevicorpus and showed the shortest hatching time than any other breeds except for P. brevicorpus.

Comparing the total length of the larval fish immediately after hatching, the average length of the catfish was $3.62 \pm 0.03 \mathrm{~mm}$. The total length of L. ussuriensis (Park et al., 2015), which belongs to the same Siluriformes fish, was $6.40 \pm 0.06 \mathrm{~mm}$ with P. fulvidraco (Kang \& Lee, 1996) 4.20-4.30 mm, P. koreanus (Kang, 1998) 5.41-6.01 mm, $P$. brevicorpus (Kang et al., 2007) $5.90 \mathrm{~mm}$, L. mediadiposalis (Choi et al., 2008) $7.31 \mathrm{~mm}$, and L. obesus (Seo et al., 2006) $7.66 \mathrm{~mm}$. And it was shorter than these, and was found to be the shortest among those compared genetic species.

Compared with the migration period to the juvenile stage, the mean length of catfish was $16.7 \pm 0.35 \mathrm{~mm}$ on the 12th day after hatching, The mean total length of $L$. ussuriensis

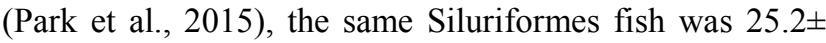
$0.71 \mathrm{~mm}$ on the 29th day after hatching, and when the size of P. fulvidraco (Kang \& Lee, 1996) was 21.6-24.0 mm on the 21 st day after hatching, it migrated. It migrated on the 8th day after hatching of P. brevicorpus (Kang et al., 2007) when the size was larger than $8.60 \mathrm{~mm}$. The size of $P$. koreanus (Kang, 1998) was 14.6-16.0 mm in length on the 
14th day after hatching, the mean length of L. obesus (Seo et al., 2006) was $16.3 \mathrm{~mm}$ on the 24 th day after hatching, and the mean length of L. mediadiposalis (Choi et al., 2008) was $16.3 \mathrm{~mm}$ on the 35 th day after hatching, demonstrating a difference according to the period. However, when their size was similar to that of the catfish, they migrated to the juvenile stage (Table 1).

Siluriformes fish are similar in morphology at the larval stage, and have difficulties in classifying early larvae because whiskers are commonly formed in the vicinity of mouth. In the catfish, two pairs of whiskers were formed on the 6th day after hatching, and four pairs of whiskers were formed on the 15th day after hatching in L. ussuriensis (Park et al., 2015), which is the same Siluriformes fish. Three pairs of whiskers were formed on the 7 th day after hatching in P. fulvidraco (Kang \& Lee, 1996). Whis- kers were formed on the 5th day after hatching in $P$. koreanus (Kang, 1998), and whiskers were formed on the 4th day after hatching in P. brevicorpus (Kang et al., 2007). Four pairs of whiskers were formed immediately after hatching in L. mediadiposalis (Choi et al., 2008) and $L$. obesus (Seo et al., 2006). Whiskers were formed most rapidly in P. brevicorpus among the Siluriformes fish. Whiskers were formed the latest in L. ussuriensis, demonstrating a difference in periods of forming mouth whiskers among species (Table 2). P. fulvidraco family fish has been attracting much taxonomical attention as it shows various characteristics such as spawning behavior characteristics, number of hatching days, external shape and skeletal trait. Despite the different genus, as it has been reported that the surface structure of the egg membrane and the movement status of the egg yolk are similar (Kang, 1998), it is

Table 1. Comparison of characteristics of eggs and larvae in the Siluriformes fish

\begin{tabular}{|c|c|c|c|c|c|}
\hline Species & $\begin{array}{c}\text { Egg } \\
\text { diameter } \\
(\mathrm{mm}, \text { mean } \pm \mathrm{SD})\end{array}$ & $\begin{array}{l}\text { Time of } \\
\text { hatching } \\
\left({ }^{*} \mathrm{WT}\right)\end{array}$ & $\begin{array}{c}\text { Hatching } \\
\text { larvae size } \\
(\mathrm{mm}, \text { mean } \pm \mathrm{SD})\end{array}$ & $\begin{array}{c}\text { Juvenile } \\
\text { size } \\
(\mathrm{mm}, \text { mean } \pm \mathrm{SD})\end{array}$ & References \\
\hline \multirow{2}{*}{ Silurus asotus } & $\begin{array}{c}1.66 \pm 0.05 \\
(1.62-1.70)\end{array}$ & $\begin{array}{l}54 \mathrm{~h} 40 \mathrm{mins} \\
\left(23.0-25.0^{\circ} \mathrm{C}\right)\end{array}$ & $\begin{array}{c}3.62 \pm 0.03 \\
(3.60-3.65)\end{array}$ & $\begin{array}{c}16.7 \pm 0.35 \\
(16.5-17.0)\end{array}$ & Present study \\
\hline & $\begin{array}{l}1.54 \pm 0.11 \\
1.47-1.61\end{array}$ & - & - & - & Midori, 1985 \\
\hline Leiocassis ussuriensis & $\begin{array}{c}2.36 \pm 0.11 \\
(2.20-2.50)\end{array}$ & $\begin{array}{l}73 \text { h } 10 \text { mins } \\
\left(24.5-26.5^{\circ} \mathrm{C}\right)\end{array}$ & $\begin{array}{c}6.40 \pm 0.06 \\
(6.33-6.50)\end{array}$ & $\begin{array}{c}25.2 \pm 0.71 \\
(24.3-26.2)\end{array}$ & Park et al., 2015 \\
\hline Pseudobagrus fulvidraco & $\begin{array}{c}1.70 \pm 0.08 \\
(1.60-1.80)\end{array}$ & $\begin{array}{c}53 \mathrm{~h} \\
\left(25.0^{\circ} \mathrm{C}\right)\end{array}$ & $(4.20-4.30)$ & $(21.6-24.0)$ & $\begin{array}{c}\text { Kang \& Lee, } \\
1996\end{array}$ \\
\hline Pseudobagrus brevicorpus & 1.99 & $\begin{array}{c}50 \mathrm{~h} \\
\left(24.0^{\circ} \mathrm{C}\right)\end{array}$ & $5.90 \pm 0.20$ & $8.60 \pm 0.50$ & $\begin{array}{l}\text { Kang et al., } \\
2007\end{array}$ \\
\hline Pseudobagrus koreanus & $\begin{array}{c}2.59 \pm 0.08 \\
(2.45-2.70)\end{array}$ & $\begin{array}{c}72 \mathrm{~h} \\
\left(21.0-23.0^{\circ} \mathrm{C}\right)\end{array}$ & $(5.41-6.01)$ & $(14.6-16.0)$ & Kang, 1998 \\
\hline Liobagrus mediadiposalis & $\begin{array}{c}3.27 \\
(2.85-3.73)\end{array}$ & $\begin{array}{c}189 \mathrm{~h} 20 \text { mins } \\
\left(22.5^{\circ} \mathrm{C}\right)\end{array}$ & $\begin{array}{c}7.31 \\
(7.18-7.39)\end{array}$ & 16.3 & $\begin{array}{c}\text { Choi et al., } \\
2008\end{array}$ \\
\hline Liobagrus obesus & $\begin{array}{c}3.30 \\
(2.95-3.92)\end{array}$ & $\begin{array}{c}225 \mathrm{~h} 15 \mathrm{mins} \\
\left(22.8^{\circ} \mathrm{C}\right)\end{array}$ & $\begin{array}{c}7.66 \\
(7.30-7.90)\end{array}$ & 16.3 & Seo et al., 2006 \\
\hline
\end{tabular}

${ }^{*}$ WT : water temperature 
Morphological Development of Eggs, Larvae and Juveniles of the Far Eastern Catfish, Silurus asotus in Korea (Pisces: Siluridae)

Table 2. Comparison of characters of the barbel number in the Siluriformes fish

\begin{tabular}{|c|c|c|c|c|c|c|c|c|c|c|}
\hline \multirow{2}{*}{ Species } & \multicolumn{10}{|c|}{ Days after hatching } \\
\hline & 0 & 1 & 3 & 4 & 5 & 6 & 7 & 9 & 10 & 15 \\
\hline \multirow{2}{*}{$\begin{array}{l}\text { Silurus asotus } \\
\text { (Present study) }\end{array}$} & (1) & (2) & & & & & & & & \\
\hline & & & & & & & & & & \\
\hline \multirow{2}{*}{$\begin{array}{l}\text { Leiocassis ussuriensis } \\
\quad \text { (Park et al., 2015) }\end{array}$} & (1) & & (2) & & & (3) & & & & (4) \\
\hline & & & & & & & & & & \\
\hline \multirow{2}{*}{$\begin{array}{l}\text { Pseudobagrus fulvidraco } \\
\text { (Kang \& Lee, 1996) }\end{array}$} & (3) & & & & & & & & & \\
\hline & & & & & & & & & & \\
\hline \multirow{2}{*}{$\begin{array}{l}\text { Pseudobagrus brevicorpus } \\
\text { (Kang et al., 2007) }\end{array}$} & & (2) & & (4) & & & & & & \\
\hline & & & & & & & & & & \\
\hline \multirow{2}{*}{$\begin{array}{c}\text { Pseudobagrus koreanus } \\
\text { (Kang, 1998) }\end{array}$} & (1) & & & & (4) & & & & & \\
\hline & & & & & & & & & & \\
\hline \multirow{2}{*}{$\begin{array}{l}\text { Liobagrus mediadiposalis } \\
\quad \text { (Choi et al., 2008) }\end{array}$} & (4) & & & & & & & & & \\
\hline & & & & & & & & & & \\
\hline Liobagrus obesus & (4) & & & & & & & & & \\
\hline
\end{tabular}

(Seo et al., 2006)

*( ) : the number of pair

necessary to review the taxonomic differences of the Siluriformes fish in the future.

\section{REFERENCES}

Choi NH, Seo WI, Kim CC, Park CK, Heo SJ, Yoon SM, Han KH, Lee WK (2008) Spawning behavior and early life history of the Liobagrus mediadiposalis in the Korean endemic species. J Korean Fish Soc 41:478-484.

Im JH, Bang JH, Noh CH, Park IS (2000) Introduction of mitotic gynogenetic diploid in the far eastern catfish, Silurus asotus. J Aquaculture 13:359-362.

Kang EJ (1998) Early life history of black bullhead, Pseudobagrus koreanus (Pisces, Bagridae), from Kum river Korea. Korean J Ichthyol 10:184-190.

Kang EJ, Lee CH (1996) Early life history of Korean bull- head, Pseudobagrus fulvidraco (Pisces, Bagridae), from Korea. Korean J Ichthyol 8:83-89.

Kang EJ, Yang H, Lee HH, Cho YC, Kim EO, Lim SG, Bang IC (2007) Ecology and early life history of endangered freshwater fish Pseudobagrus brevicorpus (Pisces: Bagridae). Korean J Environ Biol 25:378-384. Kendall AW Jr, Ahlstrom EH, Moser HG (1984) Early life history stages of fishes and their characters. In: Moser, HG et al. (eds). Ontogeny and Systematics of Fishes. Am Soc Ichthyol Herpetol Spec Publ 1:11-22 Allen Press Lawrence KS.

Kim IS, Choi Y, Lee CL, Lee YJ, Kim BJ, Kim JH (2005) Illustrated Book of Korean Fishes. Kyo Hak Publishing Seoul Korean pp. 43.

Kim JD, Do JW, Choi HS, Seo JS, Jung SH, Jo HI, Park MA, Lee NS, Park SW (2013) Pathological changes in cultuleed Korean catfish (Silurus asotus) artficially in- 
fected with Aeromonas veronii. Korean J Environ Biol 31:486-492.

Kwon AS, Kim KH, Lee YH (1998) Ultrastructure of spermatozoa in the catfish, Silurus asotus. Dev Reprod 2:75-80.

Lim SG, Kim KS, Kim YS, Han HG, Kim EO (2012) Effect of HCG, LHRHa, Ovaprim and Pimozide on ovulation indoction in long snout bullhead Leiocassis longirotris. Dev Reprod 16:137-143.

Midori K (1985) External characteristics of the eggs of Japanese catfish (Silurus). Japan J Ichthyol 32:104-106.

Park JM, Yim HS, Lee YS, Kim HY, Han KH (2015) Egg development of the ussurian bullhead fish, Leiocassis ussuriensis (Pisces: Bagridae) and morphological de velopment of its larvae and juveniles. Dev Reprod 19:189-196.

Seo WI, Han KH, Yoon SM, Kim CC, Hwang SY, Lee SH, Lee CL, Son YM, Kim IS (2006) Early life history of the Liobagrus obesus (Pisces, Amblycipitidae). Dev Reprod 10:41-45.

Song HB, Choi SS (2000) Reproductive ecology and early life history of paradise fish, Macropodus chinensis (Pisces: Belontidae) in aquarium. Korean J Limnol 33: 282-294.

Yu JH, Park SW, Kim DW (2009) Epithelioma of farmed catfish Silurus asotus in Korea. J Fish Pathol 22:107113. 